\title{
Enforcement of Property Punishment in Criminal Cases of China
}

\author{
Jing Zhao \\ Center of Criminal Law of Beijing Normal University, Beijing, China \\ Email:na.jiang@bnu.edu.cn
}

How to cite this paper: Zhao, J. (2020). Enforcement of Property Punishment in Criminal Cases of China. Chinese Studies, 9, 29-41.

https://doi.org/10.4236/chnstd.2020.91003

Received: January 22, 2020

Accepted: February 24, 2020

Published: February 27, 2020

Copyright $\odot 2020$ by author(s) and Scientific Research Publishing Inc. This work is licensed under the Creative Commons Attribution International License (CC BY 4.0).

http://creativecommons.org/licenses/by/4.0/

\begin{abstract}
The thought of social inherent concept makes the execution of property punishment lack strong support, the execution is difficult and the execution fee makes the execution of property punishment lack the impetus, which causes the vicious circle, the way of executing property punishment makes the execution of property punishment difficult to carry out vigorously, and the problems such as the convergence of the execution of the property need to be further improved. China should further improve the execution of property penalties in criminal proceedings. The execution of China's property punishment should abide by the following principles-the principle of separation of audit and execution, the principle of reference and the principle of protection of rights and interests. Procedural regulation should be carried out on the execution of property penalty in criminal proceedings.
\end{abstract}

\section{Keywords}

Enforcement of Property Punishment, Difficult Execution, China, Criminal Proceedings

\section{Introduction}

According to Article 34 of the Criminal Law of the People's Republic of China, the property penalty is an additional penalty, which is divided into a fine and a confiscation penalty. The fine penalty refers to the court's punishment for the defendant to pay a certain amount of money to the state. The confiscation of property refers to the punishment imposed by the court on the confiscation of the defendant's legally owned property, including the confiscation of some or all of the property. This type of confiscation is also called "general confiscation" in theory of criminal law. Article 64 of the Criminal Law of the People's Republic of China confiscates property related to crime, such as illegal income, contraband, 
and property for crime, which is called "special confiscation" in criminal law. Special confiscation is provided as a property penalty in some countries, while others are treated as non-penalty treatment. Our country does not provide for special confiscation as a method of punishment, but for it as a separate method of dealing with property. Therefore, there is a view that, in a strict sense, the enforcement of property punishment in our country refers only to the execution of fines and confiscation of property (general confiscation), but not the execution of special confiscation (Qiao, 2015). According to the "Several Provisions of the Supreme People's Court on the Enforcement of the Property Part of the Criminal Judgment", the execution of the property punishment part of the criminal adjudication refers to the execution matters determined by the main body of the criminal adjudication with legal effect, including: 1) Fines, confiscation of property; 2) Order restitution; 3) Dispose of stolen money and stolen goods transferred with the case; 4) Confiscate my belongings transferred with the case for use in crime; 5) Other related matters that should be executed by the people's court. In the author's opinion, in addition to the penalty and the confiscation of property, the enforcement of property rights should also include all relevant matters related to the property penalty portion of the criminal judgment enforced by the people's courts, including orders for reimbursement and disposal of stolen money and stolen goods transferred with the case.

The execution of property punishment in our country should follow the following principles: the principle of separation of trial and execution, the principle of reference and the principle of protection of rights and interests. The Criminal Procedure Law of the People's Republic of China, the Interpretation of the Application of the Criminal Procedure Law of the People's Republic of China, and the Specific Procedures and Relevant Rules for the Implementation of Property Penalties in the "Several Provisions of the Supreme People's Court on the Enforcement of the Property Part of Criminal Judgments" Matters follow these principles. In judicial practice, judicial personnel should adhere to the principle of separation of trial and execution, the principle of reference, and the principle of protection of rights and interests on the basis of clearly executing property punishment in accordance with laws and regulations.

\section{The Status Quo of Enforcement of Property Punishment in China}

Zhou Qiang, President of the Supreme People's Court, reported on the work of the Supreme People's Court at the Fourth Session of the Twelfth National People's Congress on March 13, 2016, that "it takes two to three years to basically solve the problem of difficult implementation. In China's judicial practice, the difficulty of enforcement has always been a major problem, and the difficulty of enforcement of property punishment is particularly serious. The Criminal Law of the People's Republic of China has property penalties for more than 200 counts, and more than half of the criminal law provisions involve the application 
of property penalties (Zhao, 2005). Some research reports indicate that when trying a criminal case, the courts in various places can impose property penalties according to law. The percentage of property sentences imposed in criminal cases is higher at 53\%, but the implementation of property punishments is not optimistic. The enforcement rate of property punishment is low, and the non-enforcement rate is as high as $80 \%$. The fact that property punishment has not actually been executed is widespread, and only a few cases have been enforced. The "difficulty of execution" of property punishment has plagued the judicial community, objectively undermining the seriousness and authority of court rulings, and has become a major failure of criminal justice, which urgently needs the attention of the Supreme People's Court (Song, Ma, \& Jia, 2004). So, where is the enforcement of property punishment difficult in judicial practice?

1) The Difficulties of Enforcement of Property Punishment in Judicial Practice

First of all, the inherent social ideas make the enforcement of property punishment lack strong support. People from all walks of life and even judicial executives have the concept of "hitting impunity". Affected by this concept, the defendant and his family did not realize that the nature of property punishment was a kind of punishment, and held that property punishment was similar to a fine and could not be "hit and punished" or "compensated and lost money".

Secondly, the difficulty of enforcement and the lack of enforcement fees make the enforcement of property punishment lack of motivation, resulting in a vicious circle. According to the investigation report, the defendant's voluntary payment accounted for the vast majority of the low rate of property execution. This shows that a large part of the property execution rate depends on the person being executed and the initiative of the executive is low. In addition, active payment basically takes place before the sentence, after the sentence and after the release of the sentence, the average payment per court is less than one per year. It shows that the longer the time after the case, the lower the enforcement rate. According to the survey report, the enforcement rate is only $2.13 \%$. It can be seen that the proportion of property court enforcement proceedings initiated by most courts is low, and enforcement officers are less motivated.

Thirdly, in specific judicial practice, criminals who are fined or have confiscated part of their personal property have the willingness to perform property judgments, and only need to pay the specific amount of the confiscated fine to the people's court to actively perform. However, criminals who have been confiscated all their personal property, regardless of their personal wishes, as long as they are found to have failed to perform the property judgment, they will objectively fall into a state of inability to perform. On one hand, if, after the trial has taken effect, the enforcement agency has conducted a timely investigation and enforcement of the offender's property, there will be no failure to perform the property judgment. If the offender's property is not checked and executed in a timely manner after the trial, then when the offender has been transferred to 
prison to serve his sentence, when he faces a criminal policy linked to the extent of the free sentence reduction and the performance of the property sentence, he will then try to fulfill his or her sentence during the sentence The confiscation of all personal property was convicted, but the offender was unable to pay the entire personal property because the specific scope of his personal property could not be clarified and verified. The offender is powerless to change this situation. On the other hand, after a criminal has served his sentence in prison, his personal freedom is limited to a special "closed space" such as a prison. Even if he is willing to actively perform a property judgment, it is impossible for the criminal to complete it in space. Acting in court to pay fines, receive relevant certificates, invoices, etc. At the same time, with the exception of individual criminals who have left their property impossible, during their sentence, criminals cannot normally participate in social labor and create wealth, and are unable to perform property judgments; even criminals who own property, It is already under the restriction of this special space condition of the prison, and in fact has lost direct control over its personal property, so it is unable to complete the active execution of the property judgment on its own. Relying on relatives and friends to handle related affairs on their behalf, and because criminals cannot create wealth in prison, most of the economic pressure to fulfill property judgments are actually passed on to relatives and friends who handle related affairs on their behalf. This situation is common in the practice of punishment, and as scholars pointed that, "The penalty can only be applied to the person who committed the crime, but not to the person who is not guilty". Clarified that the penalty should have the characteristic of "one body exclusiveness", as a form of punishment, property judgments should only be targeted at the offender, and the family, relatives and friends of the offender should not be involved, but this judicial practice has in many cases made the execution of the property judgment have to be involved When it comes to the offender's family, relatives and friends, this is clearly contrary to the principle of "self-responsibility" in our criminal law (Zhao, 2019).

Finally, issues such as remote implementation of convergence need to be further improved. Article 442 of the Supreme People's Court's Interpretation of the Application of the Criminal Law of the People's Republic of China stipulates that if the person being executed or the property being executed is located in a foreign country, the local people's court may be entrusted with the execution. After entrusting the execution of the property punishment, the entrusted court shall promptly hand over the executed property to the treasury. However, the issue of how to guarantee the implementation of off-site connection needs to be further solved. These include the separation of the location of the property from the location of the enforcement agency, making it difficult for foreigners to execute fines imposed remotely but based on cost considerations and local protectionism (Qiu, 2004).

2) The Enforcement of Criminal and Incidental Civil Judgments

The enforcement agency for criminal incidental civil judgments is the same as 
the enforcement agency for property punishment, and both are executed by the enforcement agency of the people's court. According to Article 438 of the Supreme People's Court's Interpretation on the Application of the Criminal Law of the People's Republic of China, property penalties and incidental civil judgments are executed by the first-instance people's court responsible for adjudication. According to Article 441, an executed person who has been sentenced to property punishment and also bears incidental civil liability shall perform civil liability first. Prior to the sentence of property, the enforced person's legitimate debts, which need to be repaid with the executed property, shall be repaid at the request of the creditor.

Enforcement of criminal collateral civil judgments in China is difficult, mainly due to imperfect legislation, imperfect judicial system, and serious local protectionism. At present, China's civil law and criminal law are not coherent in terms of regulations, which directly leads to a disconnect between litigation and enforcement in incidental civil cases. Also, criminal legislation lacks incentives for defendants with civic enforcement to consciously perform their judgments. Secondly, from the perspective of judicial practice, it is difficult for the public prosecutor, the prosecutor, and the law to take restrictive measures on the property of the defendant with a civil part. According to Articles 114 and 117 of the current Criminal Procedure Law, public security organs and people's procuratorates may, in accordance with the requirements of investigating crimes, inquire and freeze the suspect's deposits and remittances, and seize the suspect's property and interest. However, in judicial practice, in order to save money for handling cases, public security organs and people's procuratorates usually take restrictive measures against the property of criminal suspects only in the case of investigating crimes and collecting evidence of related crimes. As the verification of the defendant's personal property belonging to incidental civil execution is very complicated, in order to save case handling expenses, people's courts are usually reluctant to take the initiative to restrict the defendant's property with incidental civil part, and generally require the plaintiff with incidental civil part to provide the defendant. Due to the limited conditions and ability of the plaintiff with incidental civil parts to check the defendant's property, the judicial practice often results in the illusion that the defendant with incidental civil parts has no property to execute, resulting in the judgments of the people's courts being the same as empty papers. In addition, the Civil Procedure Law stipulates that litigation preservation is initiated during the civil trial and the people's court takes preservation measures. If a criminal incidental civil case complies with the provisions of the Civil Procedure Law and can only be filed after the incidental civil action court has filed the case, then it will take a long time from the case to the investigation and prosecution, some even years, in such a long time In the meantime, the defendant and his family had time to transfer the property safely, creating the illusion that no property was available for execution. At the same time, the Civil Procedure Law also provides that if the situation is urgent, 
the interested party may apply to the court for property preservation before the lawsuit. However, the time for civil plaintiffs to bring incidental civil lawsuits is subject to the time when criminal cases are filed, so it is difficult to control the time for prosecution.

\section{Principles of Enforcement of Property Punishment}

First, the principle of separation of trials. The Fourth Plenary Session of the Eighteenth Central Committee of the Communist Party of China clearly stated that it is necessary to further reform and improve the judicial system, and adopted the "Decision of the Central Committee of the Communist Party of China on Several Important Issues Concerning the Comprehensive Advancement of Governing the Country According to Law". Among them, "Promote the implementation of a pilot system reform that separates the power of trial from the power of execution, and optimizes the allocation of judicial powers". In the "Central Communist Party's Decision on Promoting Several Important Issues in Fully Governing the Country According to Law" (hereinafter referred to as the "Decision"), "We will improve the judicial system and promote pilot reforms of the system that separate judicial and enforcement powers". According to Article 7 of the "Several Provisions of the Supreme People's Court on the Enforcement of the Property Part of Criminal Judgment", the institution responsible for the execution of the property part of the criminal adjudication is the executive body of the People's Court, which is separate from the institution that makes the trial. The 2009 "Several Opinions of the Supreme People's Court on Further Strengthening and Standardizing the Implementation Work" and the 2011 "Several Opinions of the Supreme People's Court on the Reasonable Allocation and Scientific Operation of the Execution Power" further clearly distinguished between the enforcement power and the enforcement review power, and Requires "the implementation and execution review department established in parallel with other business courts in accordance with the decentralized operation mechanism to exercise the implementation and execution review powers respectively." Inconsistent trials can easily lead to re-examination and light execution, delays in implementation, and "difficult implementation".

Second, the reference principle. The execution of property penalties in criminal cases should follow the reference principle, that is, for matters that are not specified, the provisions of civil execution can be referred to. In China's criminal procedure laws and regulations, many of the relevant provisions on the specific issues of the enforcement of property penalties in criminal cases refer to the Civil Procedure Law. Not only that, Article 16 of the Supreme People's Court's "Several Provisions on the Enforcement of Property in Criminal Judgments" stipulates that "If the People's Court handles cases involving the execution of property in criminal adjudication, the Criminal Law, Criminal Procedure Law and relevant judicial interpretations do not have corresponding provisions. The relevant provisions of civil enforcement apply. "Article 447 of the Supreme 
People's Court's Interpretation of the Application of the Criminal Procedure Law of the People's Republic of China stipulates that" the enforcement of property penalties and incidental civil judgments is not provided for in this interpretation. The legal nature of property punishment should be defined as the debt of property that occurs according to law based on public law. The nature of the creditor's right with property as the subject matter determines the execution of property punishment with reference to the basic principles of civil execution. The execution of property punishment and civil execution may or may not be the same in terms of basic principles and system settings. Therefore, there is both commonality and mutual difference between property punishment execution and civil execution (Huang, 2014). The execution of property punishment belongs to the field of criminal-civilian interdisciplinary. To study the enforcement of property punishment, we must start from the perspective of different disciplines such as criminal law, criminal procedure law, civil substantive law, and civil procedure law. The execution of property punishment is essentially a criminal law issue, but this criminal law issue can only be improved with the help of civil substantive law, civil procedure law theory, and system norms. Only relying on the criminal law itself, it cannot independently assume the task of regulating property punishment execution. In the execution of property punishment, the criminal law, criminal procedure law, civil substantive law, and the theory and norms of civil procedure law interact and interdependent, and jointly adjust the legal relationship of property punishment execution so that the execution of property punishment has a cross-disciplinary and penal law and civil law field. On the specific operational level, the enforcement of property punishment needs to be completed with the help of civil enforcement procedures (Qiao, 2015). From the perspective of departmental law, the relevant laws and regulations on the implementation of property in China's National Procedure Law are relatively complete. They specifically stipulate enforcement opposition reconsideration, enforcement supervision, outside case opposition procedures, etc., and clearly distinguish enforcement procedures from enforcement relief procedures. From the perspective of judicial practice, China's civil law enforcement procedures have also accumulated rich judicial experience. Therefore, the implementation of property punishment in criminal cases in our country should follow the principle of reference, and refer to the provisions of civil enforcement for matters that are not regulated.

Third, the principle of protection of rights and interests. The implementation of property punishment in criminal cases should follow the principle of protection of rights and interests, that is, in the process of enforcement, attention should be paid to guaranteeing the property rights and basic living security of the person being executed, the debtor, and the family of the person being executed. This is a reflection of the contemporary humanitarianism of punishment. The people's courts must take humanitarian considerations into account when carrying out property punishment, and retain the property necessary for 
survival for the person being executed, the debtor, and the family of the person being executed. Article 9 of the Supreme People's Court's "Several Provisions on the Enforcement of Criminal Adjudications" stipulates that "the execution of confiscation of property or fines shall refer to the minimum living standard of local residents in the previous year published by the government of the domicile's domicile and retain the executed person and The living expenses of the dependents they support". The principle of protection of rights and interests is reflected in the criminal laws of various countries. Article 52 of the Russian Criminal Law of 1996 stipulates that "the property necessary for sentenced persons and their dependants shall not be confiscated in accordance with the list stipulated in the criminal reform legislation of the Russian Federation". Special attention shall be paid to the crime when the court decides to confiscate the property. The young children, the elderly and other family members who are incapacitated in the suspect's family retain the necessary means of living and production. This "necessary" property should be kept to a minimum with a basic living on the ground. Especially when the executed person is sentenced to death and the entire property is confiscated, the future life of these family members who are supported by the executed person must be taken seriously, and the property that they need to survive will be left (Wan, 2010). The Romanian Penal Code of 1969 stipulates that "the domestic and private property of criminals and their families shall not be confiscated. The property on which the criminals and their family members depend on for a living and the absolutely necessary to maintain the life of the criminals or their families, No confiscation is allowed. The scope of such property is prescribed by law. "The Criminal Law of the People's Republic of China does not determine the specific amount of property punishment, nor does it explicitly stipulate the defendant's property status as the basis for punishment. The allocation and application of property punishment are related to the safety of citizens' legal property rights. If excessive property punishment is provided, it will threaten the safety of citizens "property and conflict with the constitutional norms protecting citizens" property rights. Property punishment is both weak and severe. Compared with free punishment, property punishment is usually weak (Ruan, 2006). For the poor, the impact of a fine on their basic living standards is often self-evident; even for the rich, if they increase the amount and confiscate all their accumulated property over several generations, it may also affect their basic living security. Therefore, in the implementation of property punishment in criminal cases, our country should follow the principle of protection of rights and interests, and protect the property rights and basic living security of the person being executed, the debtor, and the family members of the person being executed.

\section{The Improvement of Enforcement of Property Punishment in China}

First, the initiation of property punishment. According to Article 7 of the "Sev- 
eral Provisions of the Supreme People's Court on the Enforcement of the Property Part of Criminal Judgments", property penalties are actively executed by the people's courts in accordance with their functions. The case filing department reviews the case. From this, it can be seen that the execution procedure is started by means of transfer by the criminal court, and there is no procedure link for application execution.

Second, the subject of enforcement of property punishment. Article 271 of China's Criminal Procedure Law stipulates that "If a criminal sentenced to a fine is not paid within the time limit, the people's court shall pay it compulsorily". Article 272 states that "the judgment on the confiscation of property shall be applied by the people regardless of whether it is additional or independent. Enforcement by the court; when necessary, it can be carried out in conjunction with the public security organs. "Article 2 of the Supreme People's Court's" Several Provisions on the Enforcement of the Property Part of Criminal Judgment "stipulates that" the property part of the criminal adjudication shall be executed by the people's court of the first instance. The people's court of first instance may entrust the people's court at the same level where the property is located to execute. Article 7 stipulates that "the criminal judgment involving the property of the people's court's execution agency, the criminal trial department shall promptly transfer the case-storing department to review the case." The subject of execution of property punishment in criminal cases in China is the executive body of the people's court.

Third, the return of property punishment. Article 15 of the Supreme People's Court's "Several Provisions Concerning the Enforcement of Part of the Property in Criminal Judgments" stipulates that "in the process of enforcement, an outsider or victim believes that the criminal judgment did not identify the property involved as stolen money or stolen property. If a written objection is submitted to the enforcement court, and the ruling can be corrected, the enforcement agency should transfer the objection materials to the criminal trial department. If the ruling cannot be corrected, the dissident should be notified to handle the trial supervision procedure". Article 443 of the Interpretation of the Criminal Procedure Law of the People's Republic of China stipulates that "In the process of executing property punishment, the people's court shall rule to suspend execution: 1) the subject matter of the execution is being tried by the people's court or arbitration agency. The disputed subject matter of the case needs to wait for the completion of the trial to determine the ownership; 2) outsiders raise objections to the execution of the subject matter; 3 ) other circumstances in which execution should be suspended. After the reasons for suspension of execution are eliminated, execution should be resumed "Article 444 states", Enforcement of property punishment. In the process, the people's court shall rule to terminate the execution in any of the following circumstances: 1) the judgment or order on which the execution is based is revoked; 2) the person being executed is executed or the death penalty is executed, and no property is available for execution 3 ) the 
unit sentenced to the penalty is terminated and no property is available for execution; 4) the penalty is exempted in accordance with Article 53 of the Criminal Law; 5) other circumstances in which execution shall be terminated. If the property of the person being executed is concealed, transferred, etc., it shall be recovered". Article 445 states that "when the property penalty is wholly or partially revoked, the property that has been executed shall be returned to the person being executed in whole or in part; if it cannot be returned, it shall be compensated according to law".

Fourth, the enforcement of property punishment. Article 271 of the Criminal Procedure Law of China stipulates that "If a criminal sentenced to a penalty is not paid within the time limit, the people's court shall compulsorily pay it". Article 4 of the Supreme People's Court "Several Provisions on the Enforcement of the Property Part of Criminal Adjudication" stipulates, If the people's court may sentence the defendant's property to criminal punishment and order reimbursement, the criminal trial department shall investigate the defendant's property status according to law; if he discovers that the property may be concealed or transferred, he shall promptly seal up, seize and freeze his corresponding property. Article 5 states that "in a criminal trial or execution, the people's court shall continue to conduct seizures, seizures, and freezes before the expiration of the time limit for the seizures, seizures, or freezes that have been taken by the investigating authority. The order is the same as the order of the seizure, seizure, and freezing of the investigating agency. The people's court may directly rule the disposal of the property seized, seized, or frozen by the investigating agency, without the need for the investigating agency to release the formalities, but the ruling should specify the seizure by the investigating agency, Seizures, freezes". Article 8 of the Several Provisions on the Implementation of the Property Part of the Criminal Judgment stipulates that "The people's court may investigate the property status of the person subject to execution by the penalty enforcement agency, community correction agency, and other relevant units, and may request relevant units to assist in seizure according to different circumstances., Seizures, freezes, transfers, and other enforcement measures". The enforcement of property punishment adopted by courts in various places varies. Some of them are transferred on time, that is, those who fail to perform within the specified period of time will be enforced in a timely manner; some will be cleaned up regularly, that is, all cases that should be enforced will be executed collectively after a certain period of time. The Xiamen Intermediate People's Court has actively explored the enforcement of property punishment. The specific approach adopted by the court is to review the situation of the offender's property that has been seized, seized, or frozen by the public security and procuratorate. The processing method is that if the detained property that should be used for the execution of property punishment has not been transferred to the court, the deduction agency will execute the execution after the court's judgment, and return the execution slip to the court. The court issued judicial advice to those who refused to 
hand over the property and refused to enforce it. While strengthening cooperation with the public security organs, the Hangzhou Xihu District Court strived to get grass-roots organizations to participate in collaboration, give full play to the role of grass-roots organizations in understanding the status of the property of the person being executed, and enhance the relevance and effectiveness of enforcement. The court of Hangzhou Chun'an County dared to be the first to explicitly stipulate in the "Interim Measures on Enforcement and Operation of Property Penalties" formulated by the court, to enforce property penalties in accordance with the relevant provisions of the Civil Procedure Law. Although this approach is reasonable, its legitimacy may be questioned, because after all, judicial reform cannot break the bottom line of the law (Song, Ma, \& Jia, 2004).

Fifth, the enforcement of property punishment. If the execution of fines and penalties encounters arrears, refusal of payment of fines, or inability to pay, it may be possible to learn from the foreign law enforcement system and adopt some alternative execution methods. The main ones are imprisonment by Yike or instructing them to participate in labor without deprivation of liberty, so that forced labor can offset the fine. Especially for incapable criminals (such as theft, robbery, drug trafficking, etc.), after the execution of the main punishment, it is more difficult to re-employ and support themselves. If the property punishment is tracked and executed, the effect is not ideal. For such criminals, the implementation of the Ike system is particularly necessary, reflecting the humanitarianism of punishment. For juveniles, it is also recommended to add a penal system for penalties. For juvenile delinquents who do not have the ability to pay, the execution of the fine penalty will be replaced by hard labor or non-deprived labor in the execution process (Song, Ma, \& Jia, 2004).

Sixth, supervision of property punishment. Procuratorial supervision of the execution of property penalties is an important part of the procuratorial supervision of the execution of penalties. The narrowly-defined procuratorial supervision of property penalties refers to the people's procuratorate's legal supervision of the people's courts' execution of fines and confiscation of property penalties. The broad-based procuratorial supervision of the execution of property penalties also includes the enforcement of court judgments, the confiscation of illegal proceeds in rulings, and other Legal supervision of the legality of the property activities involved (Shang, 2013). At present, China's legislation on the enforcement of property penalties in criminal cases is relatively lacking. There are only some general laws that should speed up the establishment of a supervision mechanism for property penalties in criminal cases. Article 129 of the Chinese Constitution stipulates that "the People's Procuratorate of the People's Republic of China is the legal supervision agency of the country", which is also the most authoritative legal basis for the procuratorate to supervise the execution of property punishment. Articles 1, 5, and 19 of the "Organization Law of the People's Procuratorate" stipulate that the procuratorate shall supervise the legality of the execution of adjudication in criminal cases. If any violation of the law 
is found, the enforcement agency shall be notified to correct it. Articles 8 and 276 of the Criminal Procedure Law of the People's Republic of China stipulate that the procuratorate shall supervise the lawfulness of the execution of punishment by the enforcement agency. Article 658 of the "People's Procuratorate's Criminal Procedure Rules (Trial)" implemented by the Supreme People's Procuratorate on January 1, 2013 further clarifies the supervision targets, scope, and contents of property punishment enforcement, especially Section 633. For the first time, this article has entrusted the procuratorial department of the people's procuratorate with supervision over the powers of supervision by legislation. China's existing legal system has gradually paid some attention to the procuratorial supervision of property punishment enforcement, but these regulations are still difficult to meet the needs of practice. In judicial practice, the ways for the procuratorate to obtain the implementation of property punishment, the specific operating procedures and rules for the procuratorate to carry out procuratorate supervision activities for property punishment enforcement, and the guarantee of the effect of the prosecutor's litigation supervision responsibilities are the enforcement agency's receipt of the corrective opinions of the procuratorate or notice of correcting violations No legal basis has been found for problems such as failing to accept opinions when writing or refusing to take corrective measures (The Task Force of the People's Procuratorate of Qinhuai District, Nanjing, 2015). Therefore, first of all, China should perfect the laws and regulations on the supervision of the execution of property punishment in criminal cases; secondly, it should give the supervisory authority the power of investigation in the supervision of the execution of property punishment; thirdly, it should clarify the subject and the content of supervision; finally, it should establish relevant supervision mechanisms.

\section{Conclusion}

The research on the enforcement of property punishment in criminal cases is of great significance to solve the problems of "difficult enforcement" in China's judicial practice. Suggestions are being taken but we still have a long way to go on this issue.

\section{Conflicts of Interest}

The authors declare no conflicts of interest regarding the publication of this paper.

\section{References}

Huang, Z. S. (2014). On the Role Sharing of the Judiciary in the Execution of Property Penalties. Criminal Science, 1, 94.

Qiao, Y. (2015). On the Legal Issues of Property Penalty Execution: Focusing on the Difficulty of Property Institutional. Journal of Law Application, 10, 98.

Qiu, J. H. (2004). Study on Certain Issues of Penalty Execution and Supervision. People's Procuratorial Semimonthly, 2, 49. 
Ruan, Q. L. (2006). On the Justification and Reform of Property Penalty. The Jurist, 1, 25-26.

Shang, A. G. (2013). Study on the System of Supervision of the Prosecution of Property Penalty Execution. People's Procuratorial Semimonthly, 18, 17.

Song, M. R., Ma, Y. L., \& Jia, K. (2004). A Survey of the Enforcement of Court Orders Against Properties. Journal of SWUPL, 5, 57.

The Task Force of the People's Procuratorate of Qinhuai District, Nanjing (2015). Study on the Supervision of the Prosecution of Property Penalty. Presentday Law Science, 2, 92.

Wan, Z. P. (2010). On Forfeiture of Property (p. 23). Chongqing: Southwest University of Political Science and Law.

Zhao, B. Z. (2005). Research on Special Topic of Criminal Policy (p. 394).

Zhao, Y. R. (2019). Research on the Difficulty of Enforcement of Property Judgments in Criminal Cases. Journal of Law Application, 23, 128-129. 